\title{
Adolescents and socialization to sexuality in same-sex families. Theoretical and methodological challenges
}

Marianna Coppola, PhD Candidate

Department of Political and Communication Sciences (DiSPC),

University of Salerno, Italy

Prof. Asoc. Giuseppe Masullo, PhD

Departement of Human, Philosophical and Educational Sciences (DISUFF), University of Salerno, Italy

\section{Abstract}

This paper aims to investigate the ways in which parents relate to the emotional and sexual lives of their adolescent children, considering the changes that occurred in the configuration of current families, at both the relational and structural level. Of these two levels, the former considers the quality of relations among family members, while the latter refers to the new family forms currently appearing within the social scenario, disarranging the traditional way of thinking about the family and originating new ways of conceiving the roles of male and female, being together, the idea of couple and - last but not least - sexuality and the various ways of living and experiencing it.

The idea is to test whether the new family configurations show different ways, compared to the traditional family, in considering children's education and managing aspects related to this stage of life. We focus here on same-sex families, with the aim of understanding the complexities determined in this specific family environment - which in many respects is still not fully recognized in Italy.

The article in the end points out the theoretical and methodological challenges that will have to be tackled in future; and relatively, it points out a research, which aims to explore the socialisation process of adolescents, and their consequent sexual approach, in the homosexual families contest.

Keywords: same-sex family/families; parenting; adolescents and sexuality; educational practices.

\section{From the traditional family to the new family forms: an ever-changing relational configuration}

Compared with traditional models, the new family configurations emerging since the $20^{\text {th }}$ century are characterized by greater emotional and communicational closeness between parents and children ${ }^{1}$. The greater openness in communications about

${ }^{1}$ This contribution results from a joint effort by the authors. More specifically and for authorship reasons, the sections 1 and 3 were written by Marianna Coppola; sections 2 and 4 were written by Giuseppe Masullo. The authors co-wrote the conclusion. 
sexuality, of both parents and children, is in tune with a relational evolution of the traditional family model, in which vertical relationships between parents and children, as well as between husband and wife, were strongly hierarchical ${ }^{2}$. This context saw the application of an authoritative educational model, based on emotional detachment, supporting the preservation of paternal authority. The division of roles was also part of the family strategies for regulating members whose individual desires, aspirations, and behaviours were subordinated and sacrificed to the family interest. Thus, the most important choices - such as working career, love, marriage and its age - became a collective bargain. Family roles were well-defined and rigid, and the relationship between parents and children was based on a series of mutual obligations ${ }^{3}$.

In the current age, the transformations affecting the family were both rapid and structural ${ }^{4}$. The transition from the traditional family to the emotional family has allowed for a more affectionate relationality and a more democratized socialization, away from the connotations of the patriarchal model, and setting greater emphasis on individuality.

Family changes, in general, are part of a large societal change, which invests the costumes and traditions of the population on multiple levels. For what concerns Italian families, there is a strong discontinuity between today's customs and what in the past was considered the norm. In fact, over the last few decades, there has been a significant decrease in the number of marriages and birth rates, as well as a rise in the age of marriage and parenthood. While the number of marriages decreases, there is an increase in separations, divorces and second marriages. This could, in part, lead to an increase in the issues related to the co-management of children and their education ${ }^{5}$.

The variability of family structures has also increased as a result of the greater number of unmarried parents, who form a family in a non-formal way ${ }^{6}$. Compared to several decades ago, becoming parents today does not seem to be taken for granted, not even for couples, as the opposite choice does not result in a loss of status anymore. Having children is therefore no longer a priority for a couple wanting to form a family, but rather a choice.

Thanks to the changes in the socio-cultural and values framework, caused by the break with pre-modern traditions, there has been a redefinition of family roles leading to the emergence of a number of family types.

\footnotetext{
${ }^{2}$ Masullo, G. and lovine F. (2016), The dynamics of eros: teenagers and socialization to sexuality in Italian atypical families, European Journal of Multidiscipliary Studies, vol. 1(4), Jan-April: 200-210

${ }^{3}$ Saraceno, C. (2012), Coppie e famiglie. Non è questione di natura, Feltrinelli, Milano.

${ }^{4}$ Donati, P. (2006), Manuale di sociologia della famiglia, Laterza, Bari - Roma

${ }^{5}$ Masullo G., lovine F., The dynamics of eros: teenagers and socialization to sexuality in Italian atypical families.

${ }^{6}$ Ruspini, E. (2012) (ed.), Studiare la famiglia che cambia, Carocci, Roma.
} 
Among the new families types, as we will see in the next section, are includes same-sex families, i.e. those made up of same-sex parents (gay, lesbian or transsexual). The difficulties experienced by them overlap only partially with what are today commonly called "domestic partnerships", as here, unlike for heterosexual couples, sexuality is a distinctive element for the dominant cultural and symbolic representation?

In light of the complexity of these family frameworks, the management of the dynamics and phases concerning the children of new families models' requires greater attention. Some issues, such as teenagers' sexuality, are highly sensitive, due to the additional dynamics and relational processes specifically pertaining to the formation of this family model.

\section{Same-sex families: new configurations and relational dynamics}

The idea that parenting is directly linked to the ability to generate children as a consequence of a natural fact - and therefore not an attitude that varies independently of sex, gender, and sexual orientation - is taken for granted. Even though having children is nowadays affranchised from marriage and natural and genetic procreation, these two aspects still constitute in the collective imagination the terms for defining what parenthood is, compared to other forms, such as same-sex parenting, which struggle to be recognized or accepted ${ }^{8}$. As La Delfa points out, "That the family goes beyond natural facts is a reality also for infertile heterosexual couples who, through medically assisted procreation, have access to a parenthood that could not happen otherwise. In addition, fertilization through third-party gametes, i.e. heterologous fertilization, occurring within the dignity and transparency of the MAP (Medically Assisted Procreation), has been the latest opening for sterile couples, but especially for homosexual couples, thus marking the beginning of their social parenthood"9.

According to Di Nicola, there is "a multiplicity of family forms that makes the use of the singular case obsolete, for an institution privatized to the point of having lost its boundaries, confused with the boundaries of the self, the subjective, the intrapsychic ${ }^{10}$. This means that homosexual parenthood is also only one of the possible forms produced by the desire and the meaning that individuals attach to the idea of family in the current age, as well as being linked to the transformations of family and parental structures. However, the recent debate has concerned not so much these aspects, but rather sexual orientations, often with ideological tones. When the border

\footnotetext{
${ }_{7}$ Licursi, S. (2014), Famiglie e socializzazione, in Grande, T. and Giap Parini, E. (eds.) Sociologia. Problemi, teorie, intrecci storici, Carocci editore, Roma.

${ }^{8}$ Paterlini, P. (2004), Matrimoni gay. Dieci storie di famiglie omosessuali, Einaudi, Torino

${ }^{9}$ La Delfa, G. (2017), Prefazione, in Parisi, R. (ed.), Coreografie familiari fra omosessualità e genitorialità, Aracne Editrice, Milano, p.9

${ }^{10}$ Di Nicola, P. (2008), Famiglia: sostantivo plurale. Amarsi, crescere e vivere nelle famiglie nel terzo millennio, FrancoAngeli, Milano, p.164
} 
between homosexuality and heterosexuality is "heavily politicized", parenthood is also placed on this "difficult border" and is captured in a field of ideological clash involving societal reproduction patterns ${ }^{11}$.

For what concerns the parental ability of homosexual couples, several studies have sought to examine whether children of this type of family would be guaranteed optimal development. They show that the child's development is more influenced by the nature of relationships and interactions in the family and other socialization agencies, rather than by the specific structural forms of the family ${ }^{12}$.

However, it should be remembered that the family is a complex social relationship, with legal (normative), economic, sexual, psychological, solidarity, cultural, affective, and external exchange dimensions. Such dimensions are always present, albeit in different measures over the centuries. In Italy, the issue of homosexual parenthood has recently been at the centre of the debate on the Cirinnà bill on civil unions. In particular, the crucial point of this bill was the stepchild adoption: the possibility for non-biological parent to adopt the partner's natural (or adoptive) child. The Cirinnà bill extended the stepchild adoption clause - already in place for heterosexual couples - also to homosexual couples. The discussion prompted by this draft law - then dismissed as part of the approval of the Cirinnà bill - had the merit of highlighting a myriad of relational constellations that may fall under the term homosexual family ${ }^{13}$.

To better clarify the characteristics of this type of family, we can resort to Di Nicola's distinction between the structural dimensions of the family and its relational aspects $^{14}$. The former designates "the people living under the same roof" and thus refers to the stable component of the family as a social system, whose characteristics are "independent from the personal traits of those who play the different roles and from the historical variability of the various family forms"15. The latter aspect, instead, refers to "how those people live under the same roof and concerns relationships, and refers to the relationships of authority, power, and affection" $" 16$.

With respect to the first dimension, we consider same-sex families as the most emblematic of the transformations undergone by the family structures. In addition, they are perhaps also the ones showing more clearly how the family as a social

\footnotetext{
${ }^{11}$ Masullo G., lovine F., The dynamics of eros: teenagers and socialization to sexuality in Italian atypical families.

${ }^{12}$ Corbisiero, F. (2017), Mamme lesbiche e i loro bambini, in Parisi R., (ed.), Coreografie familiari fra omosessualità e genitorialità, Aracne Editrice, Milano

${ }^{13}$ In using this term, we bear in mind that Saraceno (2012) considers it at times misleading, since homosexuality is an individual attribute and not a characteristic of all family members, including children, whose sexual orientation should not be associated with that of their parents.

${ }^{14}$ cfr. Di Nicola P., Famiglia: sostantivo plurale. Amarsi, crescere e vivere nelle famiglie nel terzo millennio.

${ }^{15}$ ibidem, p.17

16 ibidem, p.18
} 
construction varies according to the context and to the needs of the individuals composing it.

From the structural point of view, same-sex families can be distinguished into:

- Families formed following the end of previous heterosexual relationships;

- Planned Families (PMA);

- Planned Families (Adoption);

- Planned Families (Surrogacy)

- Co-parenting

As we will see below, the different ways in which a same-sex family has been created are important, above all, in shedding light on the set of relationships that take place, actually or potentially, within it and out of it, in an attempt to determine how parenting duties and responsibilities are shared.

Families of the first type - those formed after the end of previous heterosexual relationships - present the same difficulties faced by heterosexual couples after a separation. With regard to these families, one should consider the potentially traumatic situations that precede the formation of the new family nucleus, as well as the intersection between parental couples ${ }^{17}$. In this type of family, the homosexuality of one of the partners is not the key element, and the parent leaving the marital home may also decide to conceal his/her sexual identity to the children or, conversely, in agreement with the former partner, to unveil and express it, thus bringing the new partner into the relational sphere of the children. In this type of family, parenting continues to be carried out by parents, but in some cases the new partners may be involved, depending on the quality of the relationship between the former partners and of the parents-children relationship ${ }^{18}$.

The families of the second type, or planned families, are intensively studied to assess their parental skills. Many studies have compared same-sex and traditional planned families, focusing on three aspects: a) family characteristics; b) parenting; c) child development. In the first case, studies focused on the division of tasks and roles, highlighting the role of other significant figures (friends, relatives, etc.) who intervene in supporting this family type. The second aspect refers to the way of living and experiencing parenthood, based also on how the parents have internalized a set of models learned within the heterosexual family (including on the reproduction of gender stereotypes). The third aspect refers to the children's development, and assesses the level of psychological and social wellbeing of children growing up in these

\footnotetext{
${ }^{17}$ Tasker, F. and Patterson, CJ. (2007), Research on Gay and Lesbian Parenting: Retrospect and Prospect. Journal of GLBT Family Studies, 3 (2-3): 9-34.

${ }^{18}$ Bosisio, R. and Ronfani, P. (2015), Le famiglie omogenitoriali, Carocci, Roma.
} 
families, considering also the social stigma inevitably affecting them in an environment with heteronormative references ${ }^{19}$.

Among the planned families we can distinguish the adoptive one. As Farr and Patterson point out, although the reasons leading to adoption may coincide between homosexual and heterosexual people, the studies show a greater propensity of gay couples to adopt as a preferential way of becoming parents, as unlike heterosexual couple they do not feel the need to be biological parents ${ }^{20}$. If heterosexual couples choose adoption after numerous attempts at being biological parents, homosexual couples resort more to adoption so as not to create conflicts, nor too many distinctions between biological and social parent.

Another family form, where permitted, is to become a parent by resorting to surrogate pregnancy. This is an unregulated assisted reproduction technique (illegal in Italy) whereby a woman agrees to carry a pregnancy on behalf of a third party. The parties usually subscribe a proper contract and can choose between two types of surrogacy. The first one is the traditional type, where the gay man donates the sperm and the woman carrying the pregnancy keeps the biological bond with the baby. Alternatively, the latter tie may be snapped in the surrogacy form where the gay man also chooses the woman who will donate the ovules that will be implanted in the carrier ${ }^{21}$.

The last type of same-sex family is "co-parenting", a parental formula little known in Italy, in which the child is raised by his two fathers and his mothers in the context of a filiation bond separated from that of married couple"22. It is an agreement whereby the gay man and the lesbian woman decide to become parents, one giving the sperm and the other carrying the pregnancy. The child will thus have two biological parents and two "social" parents. Co-parents do not live together, so the father and mother of the child could imagine themselves as a separated or divorced heterosexual couple: the son lives with the lesbian couple while the gay couple enjoys visiting rights.

If we also consider that today's passage from obligation to choice is one of the distinctive features of contemporary parenthood, we need to add to the forms presented above that network of relationships and ties surrounding same-sex families. In an even more general sense, according to Parisi (2017: 98) "LGBT families express the dimension of choosing parenthood in a transparent way and, above all, constitute the most advanced reality of a kind of self-conscious kinship that elects cure, choice, and love

\footnotetext{
${ }^{19}$ Cavina C. and Danna D. (2009) (eds.), Crescere in famiglie omogenitoriali, FrancoAngeli, Milano.

${ }^{20}$ Farr R, Patterson, C (2009), Transracial adoption by lesbian, gay, and heterosexual couples: Who completes transracial adoptions and with what results? Adoption Quarterly, 12 (3-4):187-204.

${ }^{21}$ Bergman, K. Rubio, RJ. Green, R-J. and Padron, E. (2010), Gay Men Who Become Fathers via Surrogacy: The Transition to Parenthood, Journal of GLBT Family Studies, 6 (2): 111- 141

${ }^{22}$ Cadoret, A. (2002), Genitori come gli altri, Universale economica Feltrinelli, Milano, p.64
} 
as cornerstones on which to build the family and parental bond"23. It is a matter of choice, but in some cases, it is also a necessity, as breaches with the family of origin are not uncommon for gays, lesbians and transsexuals, starting with their coming out and becoming more and more acute when they form sentimental relationships.

Today, this expulsion from the family is not irreversible, legal recognition has led "the initial opposition (...) to be recomposed in new forms of intertwining, engaging and overlapping in constant evolution and transformation" ${ }^{24}$. In any case, same-sex families are supported not only by the specific contribution of the two partners, but by the complex network of subjects that include friends, relatives, or all those other significant figures that "recognize" the family in its emotional and symbolic value.

From a relational point of view - which, as mentioned above, refers to the quality of relationships between the same-sex family members - few studies have tried to outline their characteristics or to analyse the family roles, and particularly the relationship between parents and children. That is because the public debate mostly focuses on the right of homosexuals to non-sexual procreation and to a filiation not rooted in parental heterosexuality, seen as a danger to the child's harmonious growth. According to Saraceno, less attention is paid "to the complexity of relationships, affiliations, and expected mutual recognition that are triggered when a homosexual parenthood is implemented. It is this complexity and the various ways of negotiating and elaborating it in a cultural context (still) lacking the proper words to express it, which emerges instead in the experiences of those who became homosexual parents" 25 .

For what concerns couple dynamics in same-sex families, as noted by Barbagli and Colombo, there are more differences in the way men and women form and engage in the couple, regardless of sexual orientation, than between heterosexuals and homosexuals ${ }^{26}$. A research carried out by Bos, van Balen and van den Boom, which investigated the methods of day-to-day management of same-sex families, found that lesbian couples share both domestic and non-domestic tasks more fairly, because, unlike heterosexual couples, the gender polarization criterion does not influence the division of tasks. In addition, lesbian mothers seem to be more involved in caring for their children, they spend more time on it and are more emotionally involved than heterosexual mothers ${ }^{27}$.

\footnotetext{
${ }^{23}$ Parisi, R. (2017), Fare Famiglia. Processi di imparentamento e narrazioni (a)genealogiche, in Parisi R. (ed.), Coreografie familiari fra omosessualità e genitorialità, Aracne Editrice, Milano.

${ }^{24}$ Ibidem, p.98

${ }^{25}$ Saraceno, C. (2012), Coppie e famiglie. Non è questione di natura, p.119

${ }^{26}$ Barbagli, M. and Colombo, A. (2001), Omosessuali moderni. Gay e Lesbiche in Italia, Mulino, Bologna.

${ }^{27}$ Bos, HMW, van Balen, F and van den Boom DC (2007), Child adjustment and parenting in planned lesbian-parent families. American Journal of Orthopsychiatry, 77 (1): 38-48.
} 
The relationship between parents and children has perhaps been the most investigated aspect, in an attempt to bring to light the groundlessness of the idea that gays and lesbians are less able parents than heterosexual people, or that homosexuality is in itself a valid reason to prevent people from becoming parents. The results show that "The psychosocial well-being of children and teenagers raised by at least one homosexual parent can be considered standard when not higher than that experienced by children growing up in heterosexual families: the children of lesbian mothers or couples also show better scores in their attachment to parents, their perception of parents' availability, and the frequency with which issues related to emotions, school success or gender are discussed in the family" 28 .

\section{Gender and sexual identity in adolescents and the influence of same-sex families}

Sexuality is a central aspect of adolescent life, not only due to puberty, but also to educational, psychological, social, and cultural factors ${ }^{29}$.

Over the last few decades, we have witnessed a growing permissiveness of Western society, giving children and teenagers a huge amount of sexually explicit information and images. Boys and girls are often prompted, by an eroticized culture, to engage sexually even if they are not psychologically mature. Many of the obstacles to sexuality, such as fear of sin, shame or social stigma, seem to belong to the past ${ }^{30}$.

For at least two decades young people have started to have easier access to sex. Opportunities given by parents, abolishing many of the past prohibitions and constraints, to go out with friends more often and to go on holiday alone invested young people with greater self-esteem, and made them perceive their parents' greater openness on sexuality. However, in some family contexts girls still feel that they are subjected to more restrictions and a more vigilant control than boys. For this reason, they clash more often with their parents, with their choices about love and sexuality ${ }^{31}$.

An aspect of discontinuity from past generations is the age of the first sexual intercourse. Referring to the most recent available data, the National Observatory on Child and Adolescent Health (PAIDÒSS) in a 2013 survey on a sample of 1,400 teenagers aged 15 to 25 revealed that $19 \%$ of the respondents had their first sexual intercourse before the age of 14, marking an increase from $10 \%$ in 2012 and $7 \%$ in $2011^{32}$. In the same three-year period, there is a decrease in the number of adolescents declaring that

\footnotetext{
${ }^{28}$ Corbisiero, F. (2017), Mamme lesbiche e i loro bambini, in Parisi R., (ed.), Coreografie familiari fra omosessualità e genitorialità, Aracne Editrice, Milano, p.133.

${ }^{29}$ Masullo, G. (2016), I giovani tra pratiche sportive di genere e socializzazione, in Mangone, E. (ed) Adolescenti e sport. Trasformazioni sociali e pratiche motorie, FrancoAngeli, Milano.

${ }^{30}$ Bajos, N. and Bozon, M. (2008), Enquête sur la sexualité en France, Parigi, Francia, La Découverte.

${ }^{31}$ Masullo G., lovine F., The dynamics of eros: teenagers and socialization to sexuality in Italian atypical families.

32 PAIDÒSS (2013), I giovani e le Malattie a Trasmissione Sessuale, Retrieved 6 June 2017, from http://www.paidoss.it
} 
they will have sexual intercourse only after reaching majority: in 2011 they were 43\%, in 2012 they decreased to $23 \%$, and to $12 \%$ in 2012. Greater and earlier sexual activity of minors nowadays requires a more careful awareness of the risks associated with unprotected sex. On the health front, $73 \%$ of the respondents does not know at least five of the most famous STD (sexually transmitted diseases); $33 \%$ do not acknowledge the risk of HIV/AIDS and $57 \%$ think their incidence is negligible. The protections adopted by girls and boys are inadequate, as only $29 \%$ and $35 \%$ of them respectively uses the condom.

With regard to parents, some studies suggest that they limit themselves to warning children against the riskier behaviours, but avoid directly addressing the subject of sexuality ${ }^{33}$. Results show that more than half of the parents do not address issues related to their children's sexuality and a small part of them speaks of it only occasionally. Additionally, a significant portion of parents consider the sexuality of children as a private affair, thus avoiding a discussion on the matter.

The propensity to accept their children's sexual emancipation induces parents to re-elaborate their patterns and rethink their way of being parents ${ }^{34}$. Where parents exercise greater supervision and transmit sexuality-related parental values, there seems to be a better sexual health of young people. Several studies on teenagers show that families with higher communication between parents and children also register a lower sexual precociousness, greater use of condom and contraceptive methods in general, lower frequency of sexual relations and sexual partners and consequently the least risk of unwanted pregnancies and sexually transmitted diseases ${ }^{35}$.

Regarding the way in which feelings and sexuality are addressed in same-sex families, the literature review currently does not allow us to provide an accurate answer to the dilemmas experienced by same-sex parents with teenage children. However, some researches allow at least to highlight a series of typical processes in same-sex families that may be a cause of tension between parents and adolescent children.

For example, a key point for analysing how homosexual couples relate to the sphere of feelings and sexuality, is how parents transmit gender roles and stereotypes to their children ${ }^{36}$. The courtship, the approach to the other sex, the choice of the partner, the way to live the first sexual experience, are all culturally regulated aspects. Indeed, the most popular gender models, and hence the culturally established ways

\footnotetext{
${ }^{33}$ Ferrero Camoletto, R. (2008), Diventare uomini e donne: il ruolo della socializzazione alla sessualità nella costruzione dell'identità di genere, in Rauty, R. (ed.), La ricerca giovane, percorsi di analisi della condizione giovanile, Kurumuny, Calimera, Lecce.

${ }^{34}$ Miller, Brent, C. Benson, B. and Galbraith, K. A. (2001), Family relationships and adolescent pregnancy risk: A research synthesis, Developmental Review, 39:1-38.

${ }^{35}$ Browning, C. R. Leventhal, T. and Brooks-Gunn, J. (2004), Neighborhood Context and Racial Differences in Early Adolescent Sexual Activity, Demography, 41:697-720.

${ }^{36}$ Masullo G., lovine F., The dynamics of eros: teenagers and socialization to sexuality in Italian atypical families
} 
in distinguishing masculine from feminine, are what partially determines expectations and attitudes.

Bos and Sandfort, point out that lesbian and gay couples feel less pressure on sexual stereotypes related to gender and sexual orientation. The two researchers claim that the parents who personally share gender stereotypes transmit them to their children to a greater extent, while parents, such as homosexuals, who are more sensitive to such issues, pass on to their children less stereotypical behaviours and identities ${ }^{37}$. In general, gender development follows the expected paths, and the children adopted by gays and lesbians show typical features, preferences, and activities of their birth gender ${ }^{38}$. However, a study by Biblarz and Stacey reveals that children of lesbian or gay couples are more likely to show greater gender flexibility, as well as greater openness to people with a non-conforming gender or sexual identity. The same study has also investigated the gender development of children of lesbian couples compared to that of children of heterosexual parents (63 children between the ages of 8 and 12). The aspects under consideration were gender typicalities, how they relate to their own gender, pressures to conform to gender stereotypes, the degree of superiority attributed to their gender and personal inclination towards future emotional investments. The results have shown greater flexibility on gender stereotypes for children of homosexual parents: they feel less pressure, and do not perceive their gender as superior ${ }^{39}$.

Regarding sexuality, Averett, Nalavany and Ryan's research on a large sample of adoptive families (including 155 with homosexual parents and 1004 with heterosexual parents) highlights that there is no relationship between children's behavioural problems (between the ages of 1.5 and 18 years) and the parents' sexual orientation ${ }^{40}$. Erich, Kanenberg, Case, Allen and Bogdanos study on a sample of 210 teenagers adopted by 154 gay, lesbian, or heterosexual parents, shows that the parent-child relationship can never be predicted from the parent's sexual orientation. Moreover, these children do not automatically assume heterosexuality in their future relationships ${ }^{41}$.

Other studies, such as Golombok and Badger's, reveal further differences in the lives of children of lesbian mothers compared to those of heterosexual parents. In particular, they engage in a relationship later and they show a higher propensity to

\footnotetext{
${ }^{37}$ Bos, HMW. and Sandfort, T. (2010), Children's gender identity in lesbian and heterosexual two-parent families. Sex Roles, 62 (1-2): 114-126.

${ }^{38}$ Farr, R, Forssell, S and Patterson, C (2010), Parenting and child development in adoptive families: Does parental sexual orientation matter? Applied Developmental Science, 14 (3):164-178.

${ }^{39}$ Biblarz, TJ and Stacey, J (2010), How does the gender of parents matter? Journal of Marriage and Family, 72 (1): 3-22.

${ }^{40}$ Averett, P. Nalavany, B. and Ryan, S. (2009), An evaluation of gay/lesbian and heterosexual adoption. Adoption Quarterly, 12 (3-4): 129-151.

${ }^{41}$ Erich, S. Kanenberg, H. Case, K. Allen, T. Bogdanos, T. (2009), An empirical analysis of factors affecting adolescent attachment in adoptive families with homosexual and straight parents, Children and Youth Services Review, 31 (3): 398-404.
} 
envisage homosexual relationships (even though all subjects of the study declared their heterosexuality). This is also due to the greater openness they experienced in the family with regard to these issues ${ }^{42}$.

\section{Studying the sexuality of adolescents in same-sex families: theoretical challenges and methodological issues}

The literature review so far has allowed us to respond only partially to the kinds of complexity inherent in a same-sex family with regard to the sentimental and sexual experience of teenage children. It is therefore essential to undertake research on this topic to fill a cognitive gap, especially in a context like the Italian one, where the rights of same-sex families are not yet recognized. The aim of this last paragraph is also to highlight the kinds of problems that must be faced with this type of research and to describe hypotheses or interpretative paths emerging on the basis of the literature considered above.

The idea is to check whether the new family configurations' ways to consider the children's education and to handle aspects related to such a particular phase of life as adolescence are different from those of traditional families. As discussed in the previous pages, the transition from the traditional family to what is now termed "emotional" family has allowed for a more affectionate relationality and a more democratic socialization, away from the connotation of the patriarchal model, and based on a greater emphasis on individuality. The abolition of many past prohibitions has led to greater autonomy for young people, who perceive their parents' openness on the issue of sexuality ${ }^{43}$. Parental control and dialogue affects teen sexual practices: the frequency of sexual intercourse, the number of partners, the greater use of contraceptive methods, and consequently the lesser risk of unwanted pregnancies and sexually transmitted diseases. While, on the one hand, researches highlight the greater participation of parents in their children's sentimental and sexual life, on the other they are still advancing a gender-based vision, favouring the mother-daughter pair over the mother-son one, attributing an uncertain role to fathers on the sexual behaviour of their children, especially their daughters ${ }^{44}$. In same-sex families, these aspects become more complicated insofar as they give rise to configurations that, as we have seen, appear to be totally novel at the structural and relational level.

Research has also shown that new family configurations (including same-sex ones) increase the likelihood of young people engaging in sexual practices before adolescents

\footnotetext{
${ }^{42}$ Golombok, S. and Badger, S. (2010), Children raised in motherheaded families from infancy: A follow-up of children of lesbian and single heterosexual mothers, at early adulthood. Human Reproduction, 25 (1): 150-157.

${ }^{43}$ Crespi I. (2003), Il pendolo intergenerazionale. La socializzazione al genere in famiglia, Unicopli, Milano.

${ }^{44}$ Miller, Brent, C. Benson, B. and Galbraith, K. A. (2001), Family relationships and adolescent pregnancy risk: A research synthesis, Developmental Review, 39:1-38.
} 
of traditional families, thus highlighting a lower degree of parental control ${ }^{45}$. However, little emphasis is placed on the new family models of managing adolescents, that might suggest alternative ways of managing relationships as well as a more realistic understanding of love and sexuality ${ }^{46}$.

Going more in detail into the dimensions we wish to study, our future research will aim at:

- Assessing how these new configurations have changed the way people conceive traditional gender roles that, as the literature points out, are predictive of young people's attitude on their first sentimental and sexual experiences. The goal is to understand how these innovative visions are then communicated to the children, as well as how they determine the rules and ways of controlling their affective and sexual life.

- Reconstructing the relational dynamics on which the relation on the issue of control between same-sex couples is based, i.e. the agreement built by samesex couples to monitor their children's sexual and emotional lives, the issue of contraception, the risks associated with unwanted pregnancies and sexually transmitted diseases.

- Considering issues related to social stigma, and the kind of tensions that emerge in dealing with a universe with heteronormative and often homonegative; understanding, therefore, the strategies (of both parents and children) for managing these difficulties.

- Analysing how the presence in the family of other children (adolescents or not) from previous marriages or relationships of the new partner influences the relationships: the type of relationship established between the children and the parents' new partners, the division of duties and parental responsibilities.

- Exploring the assessments expressed by teenagers in these families, highlighting how family orientations may influence their thoughts and attitudes on how to live their first sentimental and sexual experiences.

When investigating what Corbisiero defines "hidden populations", the complexities of the research tools are mainly related to sampling and to attaining generalizable of results. The issues addressed, the difficulty of finding cases, the need to protect privacy (especially in the presence of minors) are all conditions that make it difficult to compose a representative sample. In this sense, the use of a snowball sampling method, starting from contacts through same-sex families' associations, appears to be the most appropriate strategy ${ }^{47}$. The type of research entails the use of qualitative

\footnotetext{
${ }^{45}$ Rosenthal D., Senserrick S. and Feldman S. (2001), A typology approach to describing parents as communicators about sexuality, in Archives of Sexual Behavior, 30(5): 463-482

${ }^{46}$ cfr. Cavina C. and Danna D. (2009) (eds.), Crescere in famiglie omogenitoriali.

${ }^{47}$ Corbisiero, F. (2017), Mamme lesbiche e i loro bambini, in Parisi R., (ed.), Coreografie familiari fra omosessualità e genitorialità, Aracne Editrice, Milano.
} 
research tools, in particular, we will carry on a semi-structured interview with the parents, followed by focus groups where the results will be discussed.

In order to overcome the methodological problems mentioned above, we will also reserve a space for the analysis of same-sex families' parents' discussions on on-line forums, in order to allow the emergence of more complex dynamics that would remain unnoticed with other research tools.

\section{Conclusions}

In recent decades, the debate on what social entity can be defined as a family has proved rather inconclusive in reaching a definite and unambiguous definition. The problem is most likely due to the need to circumscribe this entity (the family) within nature or law, while it can be defined only if one looks at the family as a kind of coexistence in constant change and transformation concerning its beginnings and the ways in which it fulfils its functions, also in relation to the increasingly complex needs of the subjectivities composing it.

In our society, the idea of family is often centred on the institution of marriage and on procreation. While these essentialized and naturalized ideas of the family survive, new visions of kinship also emerge, transcending biological facts to ground the idea of family in social practices - that is, on the spontaneous forms through which the contemporary family arises, also as a result of complex biographical paths, such as, for example, as a result of separation, or in the case of widowhood, or between two homosexuals who decide to form a family with their children of a previous heterosexual relationships.

The "normality" of heterosexual parenthood, strengthened by religious or ideological explanations, does not allow in certain countries to recognize and grant citizenship to the new "family" types, including same-sex ones, which, as seen in previous pages, are one of the many possible variations of being together and having kids in the contemporary era.

This paper therefore aimed at exploring the problems of this kind of family, and more specifically the management of the difficulties faced by homosexual parents when relating with a heteronormative-referenced cultural system. As an example of these difficulties we explored the moment when the adolescent children of these couples face their first sentimental and sexual experiences. We deem that this stage may be a crucial moment for children insofar as socialization to sexuality inevitably implies to face the outside world, the other socialization agencies - such as the peers group - and therefore the most popular gender and sex models that can create in children - given the origin of their family - feelings of inadequacy, especially with regard to the 
perception of sexual stigma. A study by Gianino, Goldberg and Lewis on homosexual couples, exploring how they relate to their peers in addressing the origins of their family, showed that only a few of them feel anxiety when revealing that they grew up in same-sex families, and that the way parents prepared their children in managing this stigma, without losing their personal and family identity, was fundamental ${ }^{48}$. The research by Bos and Van Balen mentioned above addressed the same issues and showed that while the teenagers perceive a low level of stigma when confronting with their peers, the boys had experienced episodes of exclusion and the girls were the subject of gossip. In any case, the authors highlight how parental support and also the presence of other children who undergo similar experiences are both crucial for the management of these phases ${ }^{49}$.

With regard to the teens' emotional and sexual experiences, it is conceivable that they are no different from those of their peers, even regarding their first sexual experiences. However, there are no studies on how homosexual parents address these issues, nor on how the couple manages the children's control, nor on how the issue sex-related risks is addressed, taking into account also the differences that emerge, for example, between gay and lesbian couples.

\section{Bibliography}

1. Averett, P. Nalavany, B. and Ryan, S. (2009), An evaluation of gay/lesbian and heterosexual adoption. Adoption Quarterly, 12 (3-4): 129-151.

2. Bajos, N. and Bozon, M. (2008), Enquête sur la sexualité en France, Parigi, Francia, La Découverte.

3. Barbagli, M. and Colombo, A. (2001), Omosessuali moderni. Gay e Lesbiche in Italia, Mulino, Bologna.

4. Bergman, K. Rubio, RJ. Green, R-J. and Padron, E. (2010), Gay Men Who Become Fathers via Surrogacy: The Transition to Parenthood, Journal of GLBT Family Studies, 6 (2): 111- 141.

5. Biblarz, TJ and Stacey, J (2010), How does the gender of parents matter? Journal of Marriage and Family, 72 (1): 3-22.

6. Bos, HMW. and Sandfort, T. (2010), Children's gender identity in lesbian and heterosexual two-parent families. Sex Roles, 62 (1-2): 114-126.

7. Bos, HMW, van Balen, F and van den Boom DC (2007), Child adjustment and parenting in planned lesbian-parent families. American Journal of Orthopsychiatry, 77 (1): 38-48.

\footnotetext{
48 Gianino, M. Goldberg, AE. and Lewis, T. (2009), Family Outings: Disclosure Practices Among Adopted Youth With Gay and Lesbian Parents. Adoption Quarterly, 12 (3): 205-228.

${ }^{49}$ Bos, HMW. and Sandfort, T. (2010), Children's gender identity in lesbian and heterosexual two-parent families.
} 
8. Bosisio, R. and Ronfani, P. (2015), Le famiglie omogenitoriali, Carocci, Roma.

9. Browning, C. R. Leventhal, T. and Brooks-Gunn, J. (2004), Neighborhood Context and Racial Differences in Early Adolescent Sexual Activity, Demography, 41:697-720.

10. Cadoret, A. (2002), Genitori come gli altri, Universale economica Feltrinelli, Milano.

11. Cavina C. and Danna D. (2009) (eds.), Crescere in famiglie omogenitoriali, FrancoAngeli, Milano.

12. Cirant, E. (2012), Una su cinque non lo fa. Maternità e altre scelte, FrancoAngeli, Milano.

13. Corbisiero, F. (2017), Mamme lesbiche e i loro bambini, in Parisi R., (ed.), Coreografie familiari fra omosessualità e genitorialità, Aracne Editrice, Milano.

14. Crespi I. (2003), II pendolo intergenerazionale. La socializzazione al genere in famiglia, Unicopli, Milano.

15. Curi, U. (2018). Legal Provisions, Discrimination and Uncertainty on LGBT community in Albania. Academicus International Scientific Journal, 9(17), 111121.

16. Di Nicola, P. (2008), Famiglia: sostantivo plurale. Amarsi, crescere e vivere nelle famiglie nel terzo millennio, FrancoAngeli, Milano.

17. Donati, P. (2006), Manuale di sociologia della famiglia, Laterza, Bari - Roma

18. Durkheim, É. (1893), La divisione del lavoro sociale, Edizioni di Comunità, Torino

19. Erich, S. Kanenberg, H. Case, K. Allen, T. Bogdanos, T. (2009), An empirical analysis of factors affecting adolescent attachment in adoptive families with homosexual and straight parents, Children and Youth Services Review, 31 (3): 398-404.

20. Farr, R, Forssell, S and Patterson, C (2010), Parenting and child development in adoptive families: Does parental sexual orientation matter? Applied Developmental Science, 14 (3):164-178.

21. Farr R, Patterson, C (2009), Transracial adoption by lesbian, gay, and heterosexual couples: Who completes transracial adoptions and with what results? Adoption Quarterly, 12 ( 3-4):187-204.

22. Ferrero Camoletto, R. (2008), Diventare uomini e donne: il ruolo della socializzazione alla sessualità nella costruzione dell'identità di genere, in Rauty, R. (ed.), La ricerca giovane, percorsi di analisi della condizione giovanile, Kurumuny, Calimera, Lecce.

23. Gianino, M. Goldberg, AE. and Lewis, T. (2009), Family Outings: Disclosure Practices Among Adopted Youth With Gay and Lesbian Parents. Adoption Quarterly, 12 (3): 205-228. 
24. Golombok, S. and Badger, S. (2010), Children raised in motherheaded families from infancy: A follow-up of children of lesbian and single heterosexual mothers, at early adulthood. Human Reproduction, 25 (1): 150-157.

25. La Delfa, G. (2017), Prefazione, in Parisi, R. (ed.), Coreografie familiari fra omosessualità e genitorialità, Aracne Editrice, Milano

26. Masullo, G. (2015). Homosexuality elsewhere: young migrants, sexuality and trans-cultural identity strategies. Academicus International Scientific Journal, 6(12), 120-133.

27. Masullo, G. (2016), I giovani tra pratiche sportive di genere e socializzazione, in Mangone, E. (ed) Adolescenti e sport. Trasformazioni sociali e pratiche motorie, FrancoAngeli, Milano.

28. Masullo, G. and lovine F. (2016), The dynamics of eros: teenagers and socialization to sexuality in Italian atypical families, European Journal of Multidiscipliary Studies, vol. 1(4), Jan-April: 200-210

29. Miller, Brent, C. Benson, B. and Galbraith, K. A. (2001), Family relationships and adolescent pregnancy risk: A research synthesis, Developmental Review, 39:1-38.

30. PAIDÒSS (2013), I giovani e le Malattie a Trasmissione Sessuale, Retrieved 6 June 2017, from http://www.paidoss.it

31. Parisi, R. (2017), Fare Famiglia. Processi di imparentamento e narrazioni (a) genealogiche, in Parisi R. (ed.), Coreografie familiari fra omosessualità $e$ genitorialità, Aracne Editrice, Milano.

32. Paterlini, P. (2004), Matrimoni gay. Dieci storie di famiglie omosessuali, Einaudi, Torino

33. Rosenthal D., Senserrick S. and Feldman S. (2001), A typology approach to describing parents as communicators about sexuality, in Archives of Sexual Behavior, 30(5): 463-482

34. Licursi, S. (2014), Famiglie e socializzazione, in Grande, T. and Giap Parini, E. (eds.) Sociologia. Problemi, teorie, intrecci storici, Carocci editore, Roma

35. Ruspini, E. (2012) (ed.), Studiare la famiglia che cambia, Carocci, Roma.

36. Saraceno, C. (2012), Coppie e famiglie. Non è questione di natura, Feltrinelli, Milano

37. Shtylla, A. (2013). Sexual orientation, gender identity and non-discriminationThe Albanian labor legislation and its effects on employment and vocational training potentials. Academicus International Scientific Journal, 4(07), 157-168.

38. Tasker, F. and Patterson, CJ. (2007), Research on Gay and Lesbian Parenting: Retrospect and Prospect. Journal of GLBT Family Studies, 3 (2-3): 9-34. 